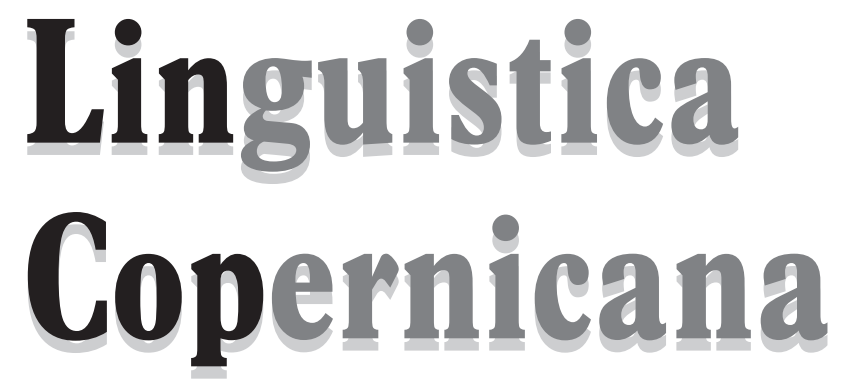

$1(7) / 2012$

WYDAWNICTWO NAUKOWE
UNIWERSytetu MIKOLAJa KOPERNIKA 
REDAKTOR NACZELnY: Maciej Grochowski

Rada Redakcyjna: Ireneusz Bobrowski (Kraków), Andrzej Bogusławski (Warszawa), Gerd Hentschel (Niemcy, Oldenburg), Axel Holvoet (Litwa, Wilno), Krystyna Kleszczowa (Katowice), Roman Laskowski (Kraków), Jarmila Panevová (Czechy, Praha), Jens Nørgård-Sørensen (Dania, Kopenhaga), Zuzanna Topolińska (Macedonia, Skopje), Daniel Weiss (Szwajcaria, Zurich), Anna Wierzbicka (Australia, Canberra)

Kole gi u m R e D K C Y J e: Maciej Grochowski, Krystyna Kallas, Irena Sawicka, Piotr Stalmaszczyk

S E K R ETA R Z R E D A K C I: Iwona Kaproń-Charzyńska

A D R E S R E D A K C J I: Instytut Języka Polskiego UMK, 87-100 Toruń, ul. Fosa Staromiejska 3, e-mail: lincop@umk.pl,www.linguistica.umk.pl

OKŁ A D K A: Monika Pest

(C) Copyright by Wydawnictwo Naukowe Uniwersytetu Mikołaja Kopernika

Toruń 2012

ISSN 2080-1068

Wersją pierwotną (referencyjną) czasopisma jest wersja papierowa.

WYDAWNICTWO NAUKOWE UNIWERSYTETU MIKOEAJA KOPERNIKA

Redakcja: ul. Gagarina 5, 87-100 Toruń

tel. (56) 6114295 , tel./fax 6114705

e-mail: wydawnictwo@umk.pl

Dystrybucja: ul. Reja 25, 87-100 Toruń

tel./fax (56) 61142 38, e-mail: books@umk.pl

www.wydawnictwoumk.pl

Druk: Wydawnictwo Naukowe UMK 


\section{Propozycja nowej kategorii zapożyczeń w językoznawstwie diachronicznym}

Słowa klucze: zapożyczenia leksykalne, klasyfikacja zapożyczeń, leksykalizacja, diachronia

Każdy język żywy ulega z natury rzeczy nieustannym zmianom. Zmiany te mogą dotyczyć różnych poziomów językowych, takich jak: fonetyka, morfologia, składnia i inne. Jak się jednak zdaje, obecnie poziomem, na którym dochodzi do największej liczby zmian jest poziom leksykalny. Ich liczba oraz dynamizm sprawiają, iż językoznawcy niekiedy za nimi nie nadążają. Dzieje się tak, po pierwsze, dlatego, że mechanizmy istniejące w każdym języku pozwalają na tworzenie w zasadzie nieskończonej liczby słów. W języku polskim można by podać dla przykładu tworzenie nowych derywatów za pomocą różnych afiksów. Po drugie: język, naszym zdaniem, odzwierciedla zmiany otaczającej nas rzeczywistości - w tym społeczeństwa.

Nowo utworzone słowa, które dzisiaj służą do nazywania różnych przedmiotów, nierzadko byłyby całkowicie niezrozumiałe dla ludzi, którzy żyli zaledwie trzydzieści, czy czterdzieści lat temu. Czat, mejl oraz jego derywat mejlować, telefon komórkowy czy też pewien niezaświadczony w żadnym znanym nam słowniku neologizm skypować, to zaledwie kilka z wielu przykładów, będących dowodem na zmiany w obrębie leksyki języka polskiego, związanych ze zmianami technologicznymi. 
Inną sferą życia społecznego, czy też publicznego, gdzie możemy dostrzec tworzenie się neologizmów, jest język polityki. Jako przykład możemy podać neologizmy utworzone poprzez antonomazję, których poprawne rozumienie wymaga pewnej wiedzy z zakresu polityki. Mamy na myśli takie słowa jak kaczyzm, korwinizm, palikotyzacja czy zapateryzm ${ }^{1}$. Neologizmy te z czasem być może wejdą do słowników, choć oczywiście nie jest to pewne.

Kolejnym przykładem zmian $\mathrm{w}$ języku, spowodowanych zmianami w społeczeństwie, jest pojawianie się np. żeńskich form nazw zawodów. Przykład, który chcielibyśmy przytoczyć, jest związany z naszym pobytem w Hiszpanii w 2010 roku. Czytując różne tamtejsze periodyki, napotykaliśmy formy juez i jueza w odniesieniu do pani sędzi, zamiast formy juez, która była tradycyjnie do niedawna używana zarówno w odniesieniu do kobiet, jak i mężczyzn². Forma jueza, choć dopuszczalna przez słowniki hiszpańskie, do tej pory używana była rzadziej, a jej coraz częstsze pojawianie się w hiszpańskich mediach, doprowadzi z czasem, w naszym przekonaniu, do powszechnego używania tej formy. Zauważmy, że w języku polskim mamy do czynienia z podobnym przypadkiem, z tą różnicą, że forma żeńska (sędzina) utworzona od formy męskiej (sędzia) często oznacza żonę sędziego, a nie panią sędzię. Wydaje się jednak, że w kontekstach formalnych jest rzadziej używana ${ }^{3}$. Tym niemniej niektóre żeńskie formy nazw zawodów, utworzone od ich męskich odpowiedników, w wielu językach wchodzą powoli do powszechnego użytku. Jest to niewątpliwie związane z emancypacją kobiet oraz z podejmowaniem przez nie funkcji, które jeszcze do niedawna były uznawane za męskie. Na podstawie przytoczonych przykładów możemy stwierdzić że: języki żywe idq z duchem czasu.

Oprócz wyżej wymienionych przyczyn zmian leksykalnych na uwagę zasługują zapożyczenia. Według Encyklopedii Językoznawstwa Ogólnego pod redakcją Kazimierza Polańskiego (dalej EJO) zapożyczenie językowe to: „Element przyjęty z obcego języka. Najczęściej jest nim wyraz (np. pol. afera $\mathrm{z}$ franc. affaire), rzadziej prefiks lub sufiks (por. pol. arcydzieło z prefiksem

1 Zapateryzm (< hiszp. zapaterismo < José Luis Rodríguez Zapatero) jest jednym z najnowszych hispanizmów w języku polskim, który na razie jednak jest neologizmem.

2 Przykładowo, w wydaniach hiszpańskiej gazety El País z 19, 26, 30 października 2010 r. pojawia się forma la jueza, natomiast w wydaniach z 21, 23, 24 października 2010 r. napotkaliśmy formę la juez.

${ }_{3}$ Podobny przypadek dotyczy np. polskich par wyrazów: prezydent-prezydentowa lub burmistrz-burmistrzowa. 
arcy- pochodzącym z grec. ó $\rho \chi l^{-}$, pocalunek z sufiksem -unek przyjętym z niem., por. niem. -ung)". Jak widzimy, według EJO, elementami najczęściej zapożyczanymi są słowa. Nie powinien więc dziwić fakt, że wielu językoznawców skupiło uwagę, właśnie na zapożyczeniach leksykalnych.

Tradycyjnie zapożyczenia te można podzielić na wiele grup na podstawie kilku podstawowych kryteriów. Pierwsze kryterium podziału zapożyczeń leksykalnych to kryterium języka, z którego dane słowo pochodzi. Tak więc wśród języków europejskich mamy np. do czynienia z anglicyzmami, bohemizmami, galicyzmami, hispanizmami, japonizmami, czyli słowami pochodzącymi odpowiednio z języków: angielskiego, np. w języku polskim bestseller $(<$ ang. bestseller), lider ( $<$ ang. leader); czeskiego, np. w języku polskim oltarz (< stcz. oltár ), msza (< stcz. mšě); francuskiego, np. w języku polskim biuletyn ( $<$ fr. bulletin), galimatias ( $<$ fr. galimatias), kamuflaż (< fr. camouflage); hiszpańskiego, np. w języku francuskim camarade ( $<$ hiszp. camarada), moustique ( $<$ hiszp. mosquito); japońskiego, np. w języku francuskim: bonsaï, haiku, czy kimono ${ }^{4}$.

Drugim kryterium podziału jest droga, którą zapożyczenie dostało się do danego języka. Z punktu widzenia tego kryterium zapożyczenia dzielimy na pośrednie, bezpośrednie oraz tzw. internacjonalizmy (Alvar Ezquerra, $2006^{6}$ [1994]: 18). Na przykład francuski czasownik tatouer 'tatuować' jest anglicyzmem, gdyż jego bezpośrednim etymonem jest angielski czasownik to tattoo. Tymczasem odpowiadający im hiszpański odpowiednik tatuar jest galicyzmem, ponieważ został zapożyczony z języka francuskiego. W konsekwencji tatouer jest anglicyzmem bezpośrednim, a hiszpańskie tatuar jest galicyzmem bezpośrednim oraz anglicyzmem pośrednim. Innym przykładem mogą być francuskie słowa: tomate 'pomidor' albo coyote 'kojot', które zostały zapożyczone z języka nahuatl za pośrednictwem języka hiszpańskiego. W języku francuskim są to więc zarówno hispanizmy bezpośrednie, jak i nahuatlizmy pośrednie (Sorbet, 2010: 184-185). Z kolei, występujący w wielu językach, internacjonalizm jest wyrazem stanowiącym z reguły pożyczkę z innego języka, który na jakimś obszarze był istotnym źródłem zapożyczeń (Perlin, 2004: 312). Jako przykład można podać słowo pochodzenia greckiego filozofia (fr. philosophie, hiszp. filosofía, ang. philosophy) albo pochodzenia łacińskiego obiektywny (hiszp. objetivo, fr. objectif, ang. objective).

${ }^{4}$ Przykłady pochodzą ze słowników etymologicznych podanych w bibliografii. 
Niekiedy jednym z kryteriów klasyfikacji zapożyczeń leksykalnych jest stopień ich przyswojenia do systemu językowego. W wypadku zapożyczeń całkowicie przyswojonych, słowa nie są odczuwane przez rodzimych użytkowników jako obce, a ich formy są całkowicie dostosowane do ortografii, fonetyki i morfoskładni danego języka, np. w języku polskim hipoteka albo msza. Jeżeli dane słowo jest powszechnie używane, ale jego forma nie została jeszcze w pełni dostosowana do systemu językowego, to mówimy o zapożyczeniach częściowo przyswojonych, np. w języku polskim kakadu albo tabu, które są nieodmienne przez przypadki. Tymczasem, jeśli wyraz zachowuje obcą pisownię i/lub wymowę, to mówimy o cytatach, np. polskie słowo baseball i hiszpańskie bestseller/best seller. Niewątpliwie jednym z najważniejszych czynników, który może świadczyć o fakcie, iż dane słowo zostało całkowicie przyswojone, jest jego zdolność do derywacji. Na przykład francuski rzeczownik chantage został zapożyczony przez język hiszpański w postaci słowa chantaje oraz przez język polski w postaci słowa szantaż. Autonomicznie rzeczowniki te utworzyły odpowiednio czasowniki chantajear oraz szantażować, podczas gdy w języku francuskim czasownik odrzeczownikowy nie istnieje. Warto podkreślić, że nowo powstałe derywaty nie są zapożyczeniami, ponieważ, jak już napisaliśmy, są one utworzone w sposób całkowicie autonomiczny. Niektórzy językoznawcy nazywają takie wyrazy, $\mathrm{tj}$. utworzone za pomocą elementu zapożyczonego oraz rodzimego morfemu hybrydami (Alvar Ezquerra, $2006^{6}$ [1994]: 18; Núñez, 1993: 41).

Wyżej podane rozróżnienia nie obejmują wszystkich możliwych zapożyczeń leksykalnych i należy jeszcze powiedzieć między innymi o ich podziale na tzw. zapożyczenia właściwe oraz zapożyczenia semantyczne. Według Perlina (2004: 331) zapożyczenie właściwe to: „Najczęściej przyjęcie obcego morfemu leksykalnego, rzadziej słowotwórczego, np. polskie bryndza z rumuńskiego. Nierzadko towarzyszy mu istotna redukcja znaczeń. Np. kliknqć (z angielskiego click) oznacza w polskim jedynie czynność wykonywaną na sprzęcie komputerowym, z pominięciem znaczenia podstawowego 'mlaskać"”.

Schematycznie można to przedstawić w sposób następujący:

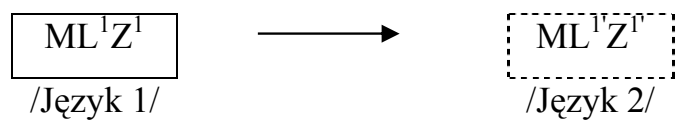


W powyższym schemacie: Język 1 to język, od którego się zapożycza; Język 2 to język, który zapożycza dany morfem leksykalny, a Z1 i Z1', to znaczenia obu morfemów leksykalnych. Warto nadmienić, że zdarzają się przypadki, w których znaczenie wyrazu, czy też morfemu leksykalnego, który został zapożyczony z Języka 1, nie odpowiada znaczeniu wyrazu z Języka 2. Przykładem może być hiszpański galicyzm chándal, którego francuski etymon chandail znaczy 'sweter', a w języku hiszpańskim znaczy 'dres'.

Tymczasem zapożyczenie semantyczne to ,zmiana lub nabranie dodatkowego znaczenia przez znak językowy wskutek wpływu znaczenia obcego odpowiednika" (Perlin 2004: 331). W języku polskim można podać wyraz mysz 'zwierzę', który został wzbogacony o nowe znaczenia 'urządzenie komputerowe' za sprawą anglicyzmu mouse.

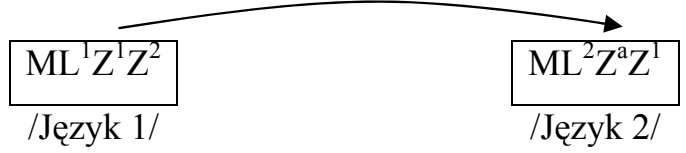

Innym przykładem zapożyczenia znaczeń poszczególnych wyrazów są tzw. kalki językowe. Są to zapożyczenia, które zostały utworzone bardzo często na skutek dosłownego tłumaczenia obcych konstrukcji za pomocą rodzimych elementów. Zgodnie z definicją EJO można je podzielić na wyrazowe np. listonosz ( $<$ niem. Briefträger) i frazeologiczne, jak zabijać czas $(<\mathrm{fr}$. tuer le temps). Innym przykładem może być angielski wyraz skyscraper, który ma swoje odpowiedniki pol. drapacz chmur, fr. gratte-ciel, hiszp. rascacielos. Schematycznie możemy to przedstawić w następujący sposób:

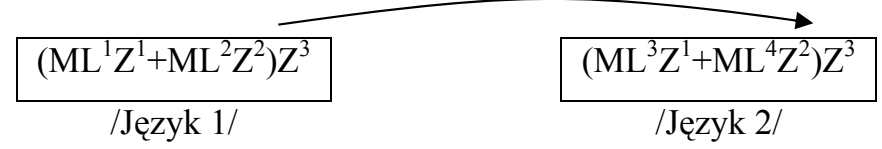

W językoznawstwie diachronicznym istnieje również pojęcie zapożyczenia sztucznego, które polega na utworzeniu neologizmu w obcym języku, w celu zapożyczenia go do słownictwa rodzimego (Perlin 2004: 330). Przykładem tego typu zapożyczeń są np. francuskie wyrazy auto-stop / autostop i tennisman 'tenisista'; te akurat słowa nazywane są również niekiedy pseu- 
doanglicyzmami, gdyż ich angielskie ekwiwalenty to odpowiednio hitch-hiking i tennis player.

Choć wymienione wyżej typy zapożyczeń leksykalnych nie wyczerpują wszystkich zaproponowanych dotychczas przez językoznawców, porównamy je z typem zapożyczenia, który jak do tej pory nie został, naszym zdaniem, opisany w sposób wystarczający. W naszej pracy typ ten nazwiemy roboczo zapożyczeniami leksykalizujacymi .

Wiemy już, czym jest zapożyczenie leksykalne, dlatego teraz postaramy się przedstawić w skrócie, czym jest leksykalizacja ${ }^{6}$. Należy powiedzieć, że zagadnieniem leksykalizacji zajmowało się już wielu językoznawców, ale ze względu na charakter naszej pracy ograniczymy się jedynie do przytoczenia dwóch definicji. Pierwsza pochodzi z EJO: „Zatarcie lub całkowita zatrata przejrzystości budowy słowotwórczej wyrazu pierwotnie motywowanego. Przyczyną leksykalizacji mogą być zmiany fonetyczne (por. np. grzeczny utworzone od pierwotnego wyrażenia $k$ rzeczy 'do rzeczy', gniew - pierwotnie derywat od *gniti, *gnoiti o znaczeniu 'zgnilizna, ropa, zepsuta krew') [...] lub znaczeniowe (por. np. słonina związane z przymiotnikiem słony). Leksykalizacja jest procesem zarówno formalnym, jak i znaczeniowym: w jej wyniku wyraz niegdyś motywowany zaczyna funkcjonować jako niemotywowany i staje się jednolitym znakiem treści realnoznaczeniowej”.

Druga definicja pochodzi ze słownika Greimas'a i Courtés'a Semiótica. Diccionario razonado de la teoría del lenguaje: "La lexicalización es el proceso durativo al que se encuentra sometida una lengua natural, y que tiene por efecto transformar un sintagma, compuesto por morfemas libres, en un sintagma fijo (o lexía) conmutable, desde el punto de vista paradigmático, dentro de una clase lexemática".

Jak widzimy, definicje te nieco się od siebie różnią. Tym niemniej obie wskazują na fakt zmian w obrębie leksyki. Pierwsza z definicji nawiązuje do wyrazu motywowanego, który zmienia się w niemotywowany, natomiast druga wskazuje, że efektem leksykalizacji jest połączenie się wolnych morfemów.

5 Przy okazji proponujemy przetłumaczenie tego terminu na język francuski jako emprunt lexicalisant i na język hiszpański jako préstamo lexicalizante.

${ }^{6}$ Dużo szczegółowiej na temat leksykalizacji pisali między innymi L. Brinton i E. Closs Traugott (2005) oraz C. Lehmann (1985). 
Przeanalizujmy teraz kilka przykładów leksykalizacji. W języku francuskim forma wyrazu lierre 'bluszcz' powstała na skutek całkowitej superpozycji morfemów le i ierre, czyli odpowiednio - rodzajnika rodzaju męskiego liczby pojedynczej i leksemu ierre. Synchronicznie morfemy te nie są podzielne. Innym wyrazem w języku francuskim, który powstał w podobny sposób, jest leksem aujourd'hui 'dzisiaj', który historycznie składa się aż z pięciu morfemów leksykalnych: ad illem diurnum de hodie (Perlin 2004: 182). W języku hiszpańskim adresatyw usted 'pan/pani' został utworzony z dwóch morfemów leksykalnych: vuestra i merced. W taki sam sposób powstał kataloński adresatyw vostè 'pan/pani', który pochodzi od wyrażenia: vostra mercè. Zarówno w języku hiszpańskim, jak i katalońskim formy te zostały utworzone z elementu pronominalnego i nominalnego. W języku angielskim możemy przytoczyć wyraz goodbye 'pożegnanie', który powstał z wyrażenia God be with you 'Niech Bóg będzie z tobą'. W jezzyku polskim ciekawym przypadkiem jest tumiwisizm, który powstał w wyniku absorpcji morfologicznej całego zdania: Tu mi wisi oraz sufiksalnego morfemu słowotwórczego -izm/-yzm. Widzimy więc, że leksykalizacji mogą ulegać zarówno różnego rodzaju syntagmy, jak i całe zdania. Co więcej, w każdym z tych przypadków, co najmniej jeden z morfemów, który tworzy nowy wyraz, zatracił swoje znaczenie semantyczne i funkcjonalne. Każdy z tych przykładów leksykalizacji powstał jednak z elementów wyłącznie należących do pojedynczego języka. Co się jednak dzieje, gdy wszystkie te elementy pochodzą z języka obcego, a do leksykalizacji dochodzi $w$ trakcie procesu zapożyczania?

W językach romańskich można znaleźć dużą liczbę słów pochodzenia arabskiego. Okazuje się, że spora część arabizmów w języku hiszpańskim i portugalskim została zapożyczona wraz z arabskim rodzajnikiem al. Tymczasem w języku francuskim i włoskim rodzajnik ten często bywał pomijany. W efekcie wiele arabizmów w dwóch pierwszych językach zaczyna się od głosek $a$ lub al:

\begin{tabular}{l||llll}
\hline \hline polski & wloski & francuski & hiszpański & portugalski \\
\hline \hline cukier & zucchero & sucre & azúcar & açúcar \\
szafran & zafferano & safran & azafrán & açafrão \\
magazyn & magazzino & magasin & almacén & armazém \\
\hline \hline
\end{tabular}


W języku hiszpańskim i portugalskim mamy więc do czynienia z wyrazami, które posiadają formy utworzone w procesie leksykalizacji, a rodzajnik arabski nie był i nie jest odczuwany jako oddzielny leksem. W konsekwencji stał się częścią nowo powstających leksemów.

Inne wyrazy, które powstały na skutek zlania się form dwóch lub większej liczby słów to np. hiszp. bigote 'wąsy', które najprawdopodobniej pochodzi od germańskiego wyrażenia bî God 'z Bogiem / na Boga'; isandié! 'o Boże! / cholera!' wykrzyknik należący do argentyńskiego lunfardo, pochodzący od francuskiego Saint Dieu 'Boże Święty'. Niezwykle interesującym wyrazem jest francuskie słowo vasistas 'lufcik', które powstało przez aglutynację całego niemieckiego zdania Was ist dass? 'Co to jest?'. Forma węgierskiego wyrazu vigéc 'domokrążca' została utworzona na wzór niemieckiego zdania pytającego Wie geht's? 'Jak się masz?' W języku polskim słowo milord pochodzi od angielskiego wyrażenia my lord '(mój) panie'.

Jak widzimy, zapożyczenia leksykalizujace występują w różnych językach. Biorąc pod uwagę wcześniej przedstawione przez nas kryteria klasyfikacji zapożyczeń leksykalnych, możemy teraz stwierdzić, że zapożyczenia leksykalizujące są bezpośrednie. Powstają one wyłącznie w wyniku bezpośredniego kontaktu użytkowników dwóch różnych języków. Z kolei, jeśli tak powstałe słowo zostanie zapożyczone przez inny język, nie będzie już zapożyczeniem leksykalizującym, ponieważ w tym procesie dojdzie do zapożyczenia wyrazu uprzednio zleksykalizowanego. Dla przykładu francuski wyraz vasistas jest germanizmem bezpośrednim i leksykalizującym, a w języku włoskim, który zapożyczył to słowo z języka francuskiego jest już galicyzmem bezpośrednim, ewentualnie germanizmem pośrednim, ale za to jedynie zapożyczeniem właściwym.

Inną cechą zapożyczeń leksykalizujących jest fakt, że dochodzi do nich zawsze drogą ustną - nigdy pisemną.

Wydaje się również, że zapożyczenia leksykalizujące są zapożyczeniami (całkowicie?) przyswojonymi. Polskie słowo milord jest w pełni przyswojone ortograficznie, fonetycznie i ma pełną deklinację. Hiszpański arabizm: alcalde (< ar. al 'rodzajnik' + qadi 'sędzia') 'burmistrz' posiada typową ortografię i wymowę dla języka hiszpańskiego. Możliwe jest również utworzenie od niego formy żeńskiej: alcaldesa 'pani burmistrz'. Galicyzm istniejący w argentyńskim lunfardo yemanfutismo 'tumiwisizm' od francuskiego zdania je m'en fous, posiada już derywat yemanfutista oraz dwie inne formy 
utworzone w lunfardo w procesie aferezy: manfutismo i manfutista świadczą o tym, że są to formy, które ulegają naturalnym przemianom wewnątrz językowych lunfardo ${ }^{7}$. Zapożyczenia leksykalizujące są zapożyczeniami całkowicie przyswojonymi, gdyż w trakcie procesu ich powstawania dochodzi z natury rzeczy - tzn. drogą ustna - niejako do automatycznej adaptacji fonetycznej, a później i ortograficznej.

Z punktu widzenia semantycznego zapożyczenia leksykalizujące mogą albo zapożyczyć znaczenie jednego z morfemów konstytuujących dane zapożyczenie leksykalizowane, np. znaczna część hiszpańskich arabizmów $\mathrm{z}$ aglutynowanym rodzajnikiem al-, albo w wyniku mylnej interpretacji desygnatu moga przyjąć całkowicie nowe znaczenie, np. wcześniej wspomniany węgierski wyraz vigéc, czy francuski vasistas.

Powyższe wnioski mogą nam teraz posłużyć do konfrontacji z tezami Weinreicha, który dzielił zapożyczenia leksykalne na proste (simple words) oraz złożone i frazy (compound words and phrases) (Weinreich 1967: 47-53). Do zapożyczeń prostych zaliczał zarówno takie, w wyniku których zapożyczano jedynie jeden morfem leksykalny, jak i takie, które są wynikiem błę$\mathrm{du}$, czy braku analizy danej formy "Accordingly, the category of ,simple” words also includes compounds that are transferred in unanalyzed form". Do drugiej grupy zalicza z kolei między innymi kalki językowe czy hybrydy. Naszym zdaniem, zapożyczenia leksykalizujące winny być traktowane oddzielnie, ponieważ sposób ich powstawania jest wyjątkowy i, jak wcześniej zauważyliśmy, mają one pewne cechy wspólne, odróżniające je od innych typów zapożyczeń.

O tym, że możliwe jest zapożyczanie na raz więcej niż jednego wolnego morfemu leksykalnego, pisało już wielu językoznawców; między innymi: Gusmani (1987), Deroy (1956), Weinreich (1967), Brinton i Clos Traugott (2005) czy Gómez Capuz (1998). Wszyscy ci sawanci, których zasług i analiz nie śmielibyśmy nawet podważać, koncentrowali się na nieco innych aspektach badań, czy to na zapożyczeniach, czy to na leksykalizacji sensu stricto.

$\mathrm{Na}$ koniec chcielibyśmy jeszcze wyjaśnić, dlaczego do nazywania tego typu zapożyczeń użyliśmy nazwy zapożyczenie leksykalizujące, a nie np. zleksykalizowane? Głównym powodem jest fakt, że chodzi w nich przede

$7 \mathrm{~W}$ formie yemanfutismo pochodzącej od francuskiego je m'en fous, występująca tam litera $t$, naszym zdaniem, jest efektem kontaminacji tej formy przez bezokolicznik francuskiego czasownika foutre. 
wszystkim o nazwanie procesu. Zwróćmy uwagę, że gdybyśmy je nazwali zapożyczeniami zleksykalizowanymi, mogłoby to zostać zinterpretowane, że słowo w chwili zapożyczania było już uprzednio zleksykalizowane, natomiast my uważamy, że do leksykalizacji dochodzi - w trakcie procesu zapożyczania.

W tej krótkiej pracy przedstawiliśmy ogólne założenia, jakimi się kierujemy, badając szczególny - naszym zdaniem - typ zapożyczenia tj. zapożyczenie leksykalizujqce. Z pewnością zabrakło tu głębszej analizy fonetycznej, morfologicznej czy semantycznej, ale uważamy, że na ich podjęcie i dalsze badania przyjdzie jeszcze czas.

\section{Bibliografia}

Alvar Ezquerra M., 2006 [1994], La formación de palabras en español, Madrid: Arco/Libros.

Baumgartner E., Ménard P., 1996, Dictionnaire étymologique et historique de la langue française, Paris: Librairie Générale Française.

Boryś W., 2008, Stownik etymologiczny języka polskiego, Kraków: Wydawnictwo Literackie.

Brinton L., Closs Traugott E., 2005, Lexicalization and language change, Cambridge: Cambridge University Press.

Bruguera J., 2006, Diccionari etimològic, Barcelona: Enciclopèdia Catalana.

Conde Ó., 2004 [1998], Diccionario etimológico del lunfardo, Buenos Aires: Taurus.

Corominas J., 2005 [2005], Breve diccionario etimológico de la lengua castellana, Madrid: Gredos.

Deroy L., 1956, L'emprunt linguistique, Paris: Société d'Édition «Les belles lettres».

Dıugosz-Kurczabowa K., 2008, Stownik etymologiczno-historyczny, Warszawa: PWN.

Gobello J., Oliveri J., 2010, Novísimo diccionario lunfardo, Buenos Aires: Corregidor.

Gómez Capuz J., 1998, El préstamo lingüistico. Conceptos, problemas y métodos, València: Universitat de València.

Greimas A. J., Courtés J., 1982, Semiótica. Diccionario razonado de la teoría del lenguaje, Madrid: Gredos.

Gusmani R., 1987, Interlinguistica, w: R. Lazzeroni (red.), Linguistica storica, Roma: NIS (La Nuova Italia Scientifica), s. 87-114.

LeHMANN C., 1985, Grammaticalization: synchronic variation and diachronic change, w: Lingua e Stile, 20, s. 303-308. 
NúÑEz S., 1993, Lenguaje e historia, Barcelona: Octaedro.

Perlin J., 2004, Metodologia językoznawstwa diachronicznego, Warszawa: Wydawnictwo Akademickie Dialog.

Piccoche J., 2002, Dictionnaire étymologique du français, Paris: Robert,

PolAŃski K. (red), 2003, Encyklopedia językoznawstwa ogólnego, Wrocław-Warszawa-Kraków: Zakład Narodowy imienia Ossolińskich.

Sorbet P., 2010, Los indigenismos americanos en la lengua francesa por conducto de la lengua española, Kwartalnik Neofilologiczny, LVII/2, s. 181-188.

WeINREICH U., 1967, Languages in contact: findings and problems, New York: Mouton.

\section{Proposal for a new category of borrowings in diachronic linguistics}

\section{( s u m m a r y)}

The aim of this article is to present the principal categories of lexical borrowings, traditionally accepted in diachronic linguistics. The presentation of this classification leads towards the acknowledgment of a category of lexical borrowings that should be treated separately, namely the lexicalizing borrowings (Fr. emprunts lexicalisants, PL. zapożyczenia leksykalizujace, Es. préstamos lexicalizantes). The examples which are used in this article come among others from: Catalan, English, French, German, Hungarian, Italian, Polish, Portuguese and Spanish. 
